\title{
IMPACT OF THE SYSTEMS OF BASIC TILLAGE AND MINERAL NUTRITION BACKGROUND ON THE PRODUCTIVITY OF GRAIN-ROW CROP ROTATION AT IRRIGATION
}

\section{Maliarchuk A. S.}

\section{INTRODUCTION}

Crop rotation is a scientifically substantiated alternation of crops in time and space, which corresponds to the natural and economic conditions of farms, biological and technical peculiarities of cultivated crops. It provides preservation and increase of soil fertility, obtaining high, stable yields at the least expenditures of labor and funds per unit of production considering environmental protection requirements ${ }^{1}$.

As the central link of the system of agriculture, a crop rotation is directed on the rational use of arable land and systematic improvement of the level of agriculture. It consists of a complex of interrelated systems: soil tillage, fertilization, irrigation, protection of plants against weeds, diseases and insects, which have to optimize the growing conditions of crops.

Scientifically based crop rotation foresees the placement of crops in space, which provides the most complete compliance with the requirements of plants to growing conditions - rational use of the first and the after effects of mineral and organic fertilizers, systems of tillage, the combination of different in intensity ways of soil cultivation, reduction of the destructive effect of tillage machinery tools and the improvement of phytosanitary condition of crops.

In general, the complex of agrotechnical and organizational measures, which are combined in a crop rotation, has to reduce the energy intensity of crop cultivation technologies, improve economic indexes, increase the efficiency of crop protection against diseases,

${ }^{1}$ Філіп’єв І. Д., Гамаюнова В. В., Димов О. М. Поживний режим грунту при полицевому i безполицевому обробітку. Зрошуване землеробство: Зб. наук. праџь. Київ: Аграрна наука, 1997. Вип. 41. С. 31-34. 
insects and reduce the risk of contamination of the environment due to the rational use of chemicals.

In the conditions of climate change, formation of the main components of highly intensive systems of irrigated agriculture with scientifically-grounded crop rotations, systems and ways and depth of tillage, doses of fertilization and optimal regimes of irrigation is a guarantee of stable crop yields.

Considering the ability of field crops not only to use, but also to effectively restore fertility of irrigated soils, a crop rotation significantly affects their biological activity, water-physical and chemical properties, the supply of plants with water, elements of mineral nutrition, as well as the ability to create a favorable phytosanitary and meliorative condition of crops and soil in agrocenosis.

In one time, the 7-8-field fruit-changing crop rotations for the diversified farms on the irrigated lands were developed, which considered their specialization, acreage area, the area of irrigated lands and their water supply.

Currently, the proposed crop rotations do not always meet the requirements of time, the law of Ukraine on "Land Protection" and the Resolution of the Cabinet of Ministers of Ukraine No. 164 dated 11.02.10 and No. 536 dated 30.06.10.

First of all, it concerns the selection of more profitable crops, their compatibility in the short crop rotation and the conditions of regulation of soil processes and their stabilization. In addition to selection of crops, it is necessary to consider the peculiarities of their individual varieties and hybrids, as well as the methods of agrotechnology. The crops cultivated in the crop rotation should meet market requirements, its demand, as well as provide high and stable profitability.

The combination of crops in the irrigated crop rotation with different effects on soil can provide optimum parameters of its properties. Conducting such researches will scientifically substantiate the peculiarities of construction of field irrigated agrophytocenosis and alternation of crops in them, which will stabilize the area of irrigated lands and increase the efficiency of their use.

The appearance of new forms of ownership and management, the share of land and the development of market relationships increased the number of enterprises with small areas of land use and narrow 
specialization. In this regard, there is a need to develop the optimum forms of land use and to introduce short crop rotations ${ }^{2}$.

It should be noted that the appropriate agricultural technology (soil tillage, application of fertilizers, use of herbicides, etc.) can diminish the negative effect of mono-crops. At the same time, it is impossible to completely replace a scientifically-based alternation of crops with other measures of agricultural technology. At the intensive agricultural production, a crop rotation obtains a main role in the phytosanitary regulation as an important biological factor of protection of plants against diseases, insects, weeds and protection of soil from contamination with harmful substances ${ }^{3,4}$.

The existing non-systematic use of irrigated lands has now led to substantial deterioration of soil fertility, reduction of their resistance to self-regulation. Under such conditions, it is necessary to substantiate scientifically the ways of stabilization of soil processes, one of which could be the optimization of placement and ratio of crops.

For the last years, significant experimental material has been accumulated in the development of scientific principles of the crop rotation construction, the ratio of crops in them, the norms of saturation of the crop rotation with cereal, industrial and forage crops were determined. Therefore, reforming agriculture, a part of which is irrigated agriculture, led to the use of new approaches to the building of crop rotations 5 .

The purpose of the article is to provide scientific substantiation of the optimum parameters of the ratio of competitive crops, minimized soil tillage and doses of nitrogen fertilizers, which will ensure the preservation of soil fertility, resource saving and an increase in productivity in the conditions of southern Steppe.

${ }^{2}$ Нетіс I. Т. Посухи та їх вплив на посіви озимої пшениці. Херсон: Айлант, 2012. $250 \mathrm{c}$.

${ }^{3}$ Системи землеробства на зрошуваних землях / за науковою редакцією Р.А. Вожегової. Київ: Аграрна наука, 2014. 264 с.

${ }^{4}$ Наукові основи виробництва органічної продукції в Україні / за науковою редакцією Я.М. Гадзала, В.Ф Камінського. Київ: Аграрна наука, 2016. 588 с.

${ }^{5}$ Коваленко А. М. Екологічні аспекти побудови сівозмін короткої ротації на зрошуваних і неполивних землях. Зрошуване землеробство. Херсон: Айлант, 2006. Вип. 45. С. 52-55. 
Materials and methods of the study. The study was carried out within the stationary research of the Institute of Irrigated Agriculture of NAAS in the 4-field link of grain-row crop rotation during 2016-2018. The scheme of the study is presented in the Table 1 . The soil of the experimental field is dark-chestnut, middle-loamy, the humus content in the arable layer is $2.06 \%$, total nitrogen content -0.103 , phosphorus -0.120 and potassium $-2.3 \%$.

According to the scheme, winter wheat, grain sorghum received mineral fertilizers dose of $\mathrm{N}_{120} \mathrm{P}_{60}$, grain corn received $\mathrm{N}_{180} \mathrm{P}_{60}$ and soybean received $\mathrm{N}_{60} \mathrm{P}_{60} \mathrm{~kg} / \mathrm{ha}$ that on average for the crop rotation was: without fertilizers, $\mathrm{N}_{82.5} \mathrm{P}_{60}$ and $\mathrm{N}_{120} \mathrm{P}_{60}$.

Agrotechnology in the experiments was generally accepted for the crops of the crop rotation in exception of the studied factors. The experiment was conducted in 4 replications. The area of sowing plot $742 \mathrm{~m}^{2}$, of the estimated one $-14 \mathrm{~m}^{2}$.

Factor A - the system of basic tillage:

1 - plowing on different depth - plowing on the depth from $14-16$ to $25-27 \mathrm{~cm}$ (control);

2 - plowless on different depth (chisel tillage at the same depth as in the control);

3 - plowless single-depth shallow (disk tillage on the depth of $12-14 \mathrm{~cm})$; rotation;

4 - differentiated- 1 with one slotting on $38-40 \mathrm{~cm}$ per the crop

5 - differentiated-2 with one plowing on $18 \mathrm{~cm}$ per the crop rotation.

Factor B (fertilization system):

1. Organic (post-harvest residues of the crops of the crop rotation);

2. Organo-mineral (post-harvest residues $+\mathrm{N}_{82.5} \mathrm{P}_{60}$ );

3. Organo-Mineral (post-harvest residues $+\mathrm{N}_{120} \mathrm{P}_{60}$ ).

The watering was carried out according to the scheme by the DDA100 MA sprinkler irrigation machine. The layout of the field experiments was performed with accordance to the methodological guidelines for the experiments at irrigation and generally accepted techniques ${ }^{6,7}$.

${ }^{6}$ Методика польових і лабораторних досліджень на зрошуваних землях: монографія / Р.А. Вожегова та ін. Херсон: Грінь Д.С., 2014. 286 с.

Статистичний аналіз результатів польових дослідів у землеробстві: монографія / Ушкаренко В.О. та ін. Херсон: Айлант, 2013. 410 с. 
Table 1

Stationary experiment scheme on the investigation of the efficiency of application of methods, techniques, depths and systems of basic soil tillage in the grain-row rotation at irrigation

\begin{tabular}{|c|c|c|c|c|c|c|}
\hline \multirow[b]{2}{*}{\begin{tabular}{l}
\multirow{7}{*}{} \\
¿ \\
$z$
\end{tabular}} & \multirow[b]{2}{*}{$\begin{array}{c}\text { Basic soil tillage } \\
\text { system }\end{array}$} & \multicolumn{4}{|c|}{ Method and depth of the basic tillage } & \multirow[b]{2}{*}{$\begin{array}{c}\text { Energy } \\
\text { capacity, } \\
\mathrm{Mj} / \mathrm{ha}\end{array}$} \\
\hline & & $\begin{array}{l}\text { Winter } \\
\text { wheat }\end{array}$ & $\begin{array}{c}\text { Sorghum } \\
\text { grain }\end{array}$ & $\begin{array}{l}\text { Grain } \\
\text { corn }\end{array}$ & Soybean & \\
\hline 1 & Plowing & $\begin{array}{c}14-16 \\
\text { (p) }\end{array}$ & $\begin{array}{l}23-25 \\
(\mathrm{p})\end{array}$ & $\begin{array}{c}20-22 \\
\text { (p) }\end{array}$ & $\begin{array}{c}25-27 \\
(\mathrm{p})\end{array}$ & 1501.6 \\
\hline 2 & Plowless & $\begin{array}{c}14-16 \\
\text { (ch) }\end{array}$ & $\begin{array}{l}23-25 \\
\text { (ch) }\end{array}$ & $\begin{array}{c}20-22 \\
\text { (ch) }\end{array}$ & $\begin{array}{c}25-27 \\
(\mathrm{ch})\end{array}$ & 871.6 \\
\hline 3 & Plowless & $\begin{array}{c}12-14 \\
\text { (d) }\end{array}$ & $\begin{array}{l}12-14 \\
\text { (d) }\end{array}$ & $\begin{array}{c}12-14 \\
\text { (d) }\end{array}$ & $\begin{array}{l}12-14 \\
\text { (d) }\end{array}$ & 499.4 \\
\hline 4 & Differentiated-1 & $\begin{array}{l}8-10 \\
\text { (d) }\end{array}$ & $\begin{array}{c}12-14 \\
(\mathrm{ch})+ \\
+38-40 \\
(\mathrm{sl})\end{array}$ & $\begin{array}{l}8-10 \\
\text { (d) }\end{array}$ & $\begin{array}{l}14-16 \\
\text { (d) }\end{array}$ & 697.7 \\
\hline 5 & Differentiated-2 & $\begin{array}{l}10-12 \\
\text { (d) }\end{array}$ & $\begin{array}{l}16-18 \\
\text { (ch) }\end{array}$ & $\begin{array}{c}18-20 \\
\text { (p) }\end{array}$ & $\begin{array}{l}14-16 \\
\text { (d) }\end{array}$ & 800.0 \\
\hline
\end{tabular}

Note: $\mathrm{p}$ - plowing; ch - a chisel loosening; $\mathrm{d}$ - disk tillage; $\mathrm{sl}$ - slotting.

\section{Agrophysical Properties of soil}

The use of tools with different construction of working bodies for soil tillage to a certain extent affects the whole complex of agrophysical properties of soil, including the bulk density, porosity and water permeability.

Our study found that the methods, techniques and depth of tillage had a significant effect on the bulk density (Table 2).

Thus, at the beginning of the spring vegetation, the closest to the optimum indexes for the crops of the crop rotation were the different depth tillage and differentiated-1 tillage systems, by the time of harvesting the compaction of the soil in all the studied variants occurs, at the same time, the most significant it was in the variant of a singledepth shallow plowless tillage (var. 3) 
Table 2

The bulk density of dark-chestnut soil in different systems of basic soil tillage in the crop rotation, $\mathrm{g} / \mathrm{cm}^{3}$

\begin{tabular}{|c|c|c|c|c|c|c|}
\hline \multirow[b]{2}{*}{ No. } & \multirow{2}{*}{$\begin{array}{c}\text { Basic } \\
\text { soil tillage } \\
\text { system }\end{array}$} & \multicolumn{4}{|c|}{ Bulk density, $\mathrm{g} / \mathrm{cm}^{3}$} & \multirow{2}{*}{$\begin{array}{l}\text { On average } \\
\text { by the crop } \\
\text { rotation }\end{array}$} \\
\hline & & Grain corn & Sorghum & $\begin{array}{l}\text { Winter } \\
\text { wheat }\end{array}$ & Soybean & \\
\hline \multicolumn{7}{|c|}{ At the beginning of vegetation } \\
\hline 1 & $\begin{array}{l}\text { Plowing on } \\
\text { different depth }\end{array}$ & 1.26 & 1.28 & 1.26 & 1.26 & 1.27 \\
\hline 2 & $\begin{array}{l}\text { Plowless on } \\
\text { different depth }\end{array}$ & 1.28 & 1.29 & 1.28 & 1.28 & 1.28 \\
\hline 3 & \begin{tabular}{|l} 
Plowless \\
single-depth
\end{tabular} & 1.32 & 1.33 & 1.32 & 1.32 & 1.32 \\
\hline 4 & Differentiated-1 & 1.27 & 1.27 & 1.30 & 1.29 & 1.28 \\
\hline 5 & Differentiated-2 & 1.28 & 1.31 & 1.31 & 1.31 & 1.30 \\
\hline \multicolumn{7}{|c|}{ Before harvesting } \\
\hline 1 & $\begin{array}{l}\text { Plowing on } \\
\text { different depth }\end{array}$ & 1.28 & 1.29 & 1.28 & 1.28 & 1.28 \\
\hline 2 & $\begin{array}{l}\text { Plowless on } \\
\text { different depth }\end{array}$ & 1.30 & 1.30 & 1.30 & 1.30 & 1.30 \\
\hline 3 & \begin{tabular}{|l} 
Plowless \\
single-depth
\end{tabular} & 1.34 & 1.35 & 1.35 & 1.35 & 1.35 \\
\hline 4 & Differentiated-1 & 1.27 & 1.29 & 1.33 & 1.32 & 1.30 \\
\hline 5 & Differentiated-2 & 1.31 & 1.32 & 1.33 & 1.33 & 1.32 \\
\hline
\end{tabular}

Determination of the bulk density in the soil layer 0-40 cm under the influence of different systems of soil tillage gave the possibility to determine the fluctuations in the studied index within the range of $1.27-1.32 \mathrm{~g} / \mathrm{cm}^{3}$ in the period of sprouting. The most loosened was the soil layer of $0-40 \mathrm{~cm}$ in the variant of different-depth plowing (var. 1) in the crop rotation, where the bulk density averaged to $1.27 \mathrm{~g} / \mathrm{cm}^{3}$.

Application of a single-depth shallow $(12-14 \mathrm{~cm})$ disking of the soil in the crop rotation led to the increase in the bulk density by $0.05 \mathrm{~g} / \mathrm{cm}^{3}$ or by $3.9 \%$. 
The closest to the control by its influence on the soil is the 4-th variant with differentiated-1 system of basic tillage. In all the years of the study the difference between the control and this variant for did not exceed $0.01 \mathrm{~g} / \mathrm{cm}^{3}$ or was insignificant.

The same regularity was observed before harvesting. The tendency to over-compaction of the upper layers saved that led to the formation of the increased indexes of the bulk density of the soil layer 0-40 cm, which fluctuated within $1.28-1.35 \mathrm{~g} / \mathrm{cm}^{3}$.

During the vegetation, a different-depth plowing and differentiated-1 systems of the basic tillage (var. 1, 4) provided a relatively close by the bulk density arable layer of the soil, and the plowless shallow one (var. 3) resulted in the separation of the arable layer into more loose upper $(0-15 \mathrm{~cm})$ and more compacted bottom $(15-40 \mathrm{~cm})$ parts due to the concentration of the post-harvest residues in the upper part of the arable layer at the tillage with the working bodies of the disk type.

Thus, on average for three years of the use in the experiment, plowing on different depth and differentiated-1 systems of basic soil tillage ensured the formation of the optimum indexes of the bulk density for the crops of the crop rotation at the stage of sprouting and initial stages of organogenesis. By the time of harvesting, the indexes of the bulk density increased, and at the same time the regularity determined at the spring time remained actual.

The porosity of the soil directly depended on its bulk density. The more compacted the soil was, the lower its porosity was, that complicated absorption and infiltration of water in the zone of root system placement.

The results of the experimental researches, obtained in our study, testify that at the stage of sprouts the indexes of total porosity of the soil layer $0-40 \mathrm{~cm}$ were almost equal, although the tendency to their increase was observed in the variants of plowing and plowless different-depth and differentiated-1 tillage systems. The difference between the variants was only $1.3 \%$ (Table 3 ).

The same regularity was determined before harvesting yield almost in all the variants. In the variant of different-depth plowing basic tillage of the soil (variant 1) the total porosity was within the optimal parameters and averaged to $50.86 \%$, while in the variant of shallow single-depth tillage it was only $48.40 \%$, i.e. decreased by $4.8 \%$ in comparison to the control variant. 
Table 3

Porosity of the dark-chestnut soil at different systems of basic soil tillage in the crop rotation, $\%$

\begin{tabular}{|c|c|c|c|c|c|c|}
\hline \multirow[b]{2}{*}{ No. } & \multirow[b]{2}{*}{$\begin{array}{c}\text { Basic soil tillage } \\
\text { system }\end{array}$} & \multicolumn{4}{|c|}{ Porosity, $\%$} & \multirow{2}{*}{$\begin{array}{c}\text { On average } \\
\text { by the crop } \\
\text { rotation }\end{array}$} \\
\hline & & Grain corn & Sorghum & $\begin{array}{l}\text { Winter } \\
\text { wheat }\end{array}$ & Soybean & \\
\hline \multicolumn{7}{|c|}{ At the beginning of vegetation } \\
\hline 1 & $\begin{array}{l}\text { Plowing on } \\
\text { different depth }\end{array}$ & 51.85 & 50.96 & 51.60 & 51.72 & 51.53 \\
\hline 2 & $\begin{array}{l}\text { Plowless on } \\
\text { different depth }\end{array}$ & 50.83 & 50.57 & 50.96 & 51.09 & 50.86 \\
\hline 3 & $\begin{array}{l}\text { Plowless } \\
\text { single-depth }\end{array}$ & 49.55 & 49.17 & 49.30 & 49.30 & 49.33 \\
\hline 4 & Differentiated-1 & 51.47 & 51.21 & 50.32 & 50.45 & 50.86 \\
\hline 5 & Differentiated-2 & 50.96 & 49.81 & 49.68 & 49.81 & 50.06 \\
\hline \multicolumn{7}{|c|}{ Before harvesting } \\
\hline 1 & $\begin{array}{l}\text { Plowing on } \\
\text { different depth }\end{array}$ & 50.96 & 50.57 & 50.96 & 50.96 & 50.86 \\
\hline 2 & $\begin{array}{l}\text { Plowless on } \\
\text { different depth }\end{array}$ & 50.32 & 50.06 & 50.19 & 50.32 & 50.22 \\
\hline 3 & $\begin{array}{l}\text { Plowless } \\
\text { single-depth }\end{array}$ & 48.66 & 48.40 & 48.28 & 48.28 & 48.40 \\
\hline 4 & Differentiated-1 & 51.21 & 50.70 & 49.17 & 49.55 & 50.16 \\
\hline 5 & Differentiated-2 & 49.94 & 49.30 & 48.91 & 49.04 & 49.30 \\
\hline
\end{tabular}

Significant differences by the years of the study were not determined.

It is possible only to mention the reduction of the total porosity to the optimum indexes for the crops of the crop rotation from sowing to the harvesting in all the variants of basic tillage and in the layers of arable horizon. 
Thus, the most loosened soil was in the variant of different-depth plowing in the crop rotation and it corresponded to the optimum indexes of the plants growth and development.

The results of our researches testify that the methods of basic tillage have the effect on the soil water permeability. Mostly its index depends on the depth of loosening.

In the case of determination of the water-permeability of the soil after the sprouting stage of the crops, it was within the optimum values through all the studied variants. The highest it was in the variant of plowing on the background of prolonged use of different-depth plowing basic tillage in the crop rotation and averaged by 3 years of the study at the 3-hour exposition to $3.92 \mathrm{~mm} / \mathrm{min}$. Switch form plowing to chisel tillage on the same depth led to the decrease of water-permeability by $11.5 \%$, and the substitution with shallow disk tillage - by $26.8 \%$ with the indexes 3.47 and $2.87 \mathrm{~mm} / \mathrm{min}$, respectively.

At the end of the vegetation of the crops of the crop rotation, the indexes of water-permeability decreased in comparison to the initial ones, that is connected with the compaction of the soil due to the solar radiation effect, atmospheric precipitation, irrigation water, running gears of tractors and working bodies of tillage machines.

The results of the analysis of the experimental researches by the years of the study proved the observed at the beginning of vegetation regularity. The highest water-permeability of the soil before the period of harvesting was at the different-depth plowing with the index of $3.44 \mathrm{~mm} / \mathrm{min}$, while at the variant with shallow tillage plowless singledepth tillage $(12-14 \mathrm{~cm})$ it was $2.31 \mathrm{~mm} / \mathrm{min}$ or was less by $32.8 \%$. Differentiated-1 tillage system of basic tillage was close to the different-depth plowing with the index of $3.07 \mathrm{~mm} / \mathrm{min}$ (Table 4).

So, the studies, conducted during 3 years, provide the possibility to conclude that the depth of basic tillage plays a decisive role in the formation of water-permeability of the soil and water supply of the plants.

The process of the reduction of water-permeability of the soil depending on the basic tillage before sowing and harvesting is under the effect of hydrothermal conditions of autumn-winter and springsummer period and compaction action of tractors running gears and working bodies of tillage machines, sowing and harvesting machinery. 
Table 4

Water permeability of the dark-chestnut soil under the different basic soil tillage systems in the crop rotation, $\mathrm{mm} / \mathrm{min}$

\begin{tabular}{|c|c|c|c|c|c|c|}
\hline \multirow[b]{2}{*}{ No. } & \multirow{2}{*}{$\begin{array}{c}\text { Basic } \\
\text { soil tillage } \\
\text { system }\end{array}$} & \multicolumn{4}{|c|}{ Water permeability, $\mathrm{mm} / \mathrm{min}$} & \multirow{2}{*}{$\begin{array}{l}\text { On average } \\
\text { by the crop } \\
\text { rotation }\end{array}$} \\
\hline & & Grain corn & Sorghum & $\begin{array}{l}\text { Winter } \\
\text { wheat }\end{array}$ & Soybean & \\
\hline \multicolumn{7}{|c|}{ At the beginning of vegetation } \\
\hline 1 & $\begin{array}{l}\text { Plowing on } \\
\text { different depth }\end{array}$ & 4.27 & 4.30 & 3.33 & 3.77 & 3.92 \\
\hline 2 & $\begin{array}{l}\text { Plowless on } \\
\text { different depth }\end{array}$ & 3.90 & 3.70 & 2.90 & 3.37 & 3.47 \\
\hline 3 & $\begin{array}{l}\text { Plowless } \\
\text { single-depth }\end{array}$ & 3.30 & 3.13 & 2.33 & 2.70 & 2.87 \\
\hline 4 & Differentiated-1 & 3.90 & 4.33 & 2.73 & 3.23 & 3.55 \\
\hline 5 & Differentiated-2 & 3.97 & 3.57 & 2.33 & 2.97 & 3.21 \\
\hline \multicolumn{7}{|c|}{ Before harvesting } \\
\hline 1 & $\begin{array}{l}\text { Plowing on } \\
\text { different depth }\end{array}$ & 3.83 & 3.70 & 3.07 & 3.17 & 3.44 \\
\hline 2 & $\begin{array}{l}\text { Plowless on } \\
\text { different depth }\end{array}$ & 3.27 & 3.10 & 2.60 & 2.77 & 2.93 \\
\hline 3 & \begin{tabular}{|l} 
Plowless \\
single-depth
\end{tabular} & 2.87 & 2.43 & 1.87 & 2.07 & 2.31 \\
\hline 4 & Differentiated-1 & 3.53 & 3.77 & 2.37 & 2.60 & 3.07 \\
\hline 5 & Differentiated-2 & 3.43 & 3.03 & 2.00 & 2.37 & 2.71 \\
\hline
\end{tabular}

\section{Crop yields in the crop rotation}

Under the influence of basic soil tillage systems, there were the changes of agrophysical properties, nutrition regime that caused the creation of different conditions for growth and development of the crops and yield formation. As a result, different yields of the crops in the crop rotation were formed.

The doses of fertilizer also had a valuable influence on the yield formation. Thus, on average for three years of the study, it was found 
that the highest yields in the crop rotation were provided by the application of fertilizers in the dose of $\mathrm{N}_{120} \mathrm{P}_{60}$ on the background of different-depth plowing and differentiated-1 systems. Thus, the yield of grain corn was 14.44 and $14.82 \mathrm{t} / \mathrm{ha}$, respectively, soybean -4.31 and $4.34 \mathrm{t} / \mathrm{ha}$, winter wheat 6.81 and $6.90 \mathrm{t} / \mathrm{ha}$ and sorghum grain 7.09 and 7.70 t/ha (Table 5).

Table 5

Yields of the crops of the short crop rotation at different systems of basic soil tillage and doses of fertilizers, for 2016-2018

\begin{tabular}{|c|c|c|c|c|c|c|c|}
\hline \multirow[b]{2}{*}{$\begin{array}{l}\text { Basic soil tillage } \\
\text { system (factor A) }\end{array}$} & \multirow{2}{*}{$\begin{array}{c}\text { Nutrition } \\
\text { background } \\
\text { (Factor B) }\end{array}$} & \multicolumn{4}{|c|}{ The crop of the crop rotation } & \multicolumn{2}{|c|}{$\begin{array}{l}\text { Average } \\
\text { by factor }\end{array}$} \\
\hline & & $\begin{array}{l}\text { Winter } \\
\text { wheat }\end{array}$ & $\begin{array}{l}\text { Corn } \\
\text { for } \\
\text { Grain }\end{array}$ & Soy & $\begin{array}{c}\text { Sorghum } \\
\text { grain }\end{array}$ & A & B \\
\hline \multirow{3}{*}{$\begin{array}{l}\text { Plowing } \\
\text { (control) }\end{array}$} & $\begin{array}{l}\text { Without } \\
\text { fertilizer } \\
\text { (control) }\end{array}$ & 3.15 & 4.26 & 2.76 & 2.89 & \multirow[t]{3}{*}{6.15} & 2.98 \\
\hline & $\mathrm{N}_{82.5} \mathrm{P}_{60}$ & 6.01 & 11.43 & 3.68 & 6.90 & & 6.46 \\
\hline & $\mathrm{N}_{120} \mathrm{P}_{60}$ & 6.81 & 14.44 & 4.34 & 7.09 & & 7.51 \\
\hline \multirow{3}{*}{ Plowless } & $\begin{array}{l}\text { Without } \\
\text { fertilizers }\end{array}$ & 3.01 & 3.81 & 2.48 & 2.51 & \multirow{3}{*}{5.73} & \\
\hline & $\mathrm{N}_{82.5} \mathrm{P}_{60}$ & 5.53 & 10.81 & 3.34 & 6.58 & & \\
\hline & $\mathrm{N}_{120} \mathrm{P}_{60}$ & 6.25 & 13.64 & 3.98 & 6.81 & & \\
\hline \multirow{3}{*}{ Plowless } & $\begin{array}{l}\text { Without } \\
\text { fertilizers }\end{array}$ & 2.70 & 3.05 & 1.77 & 2.04 & \multirow{3}{*}{4.46} & \\
\hline & $\mathrm{N}_{82.5} \mathrm{P}_{60}$ & 5.26 & 8.16 & 2.41 & 4.59 & & \\
\hline & $\mathrm{N}_{120} \mathrm{P}_{60}$ & 5.91 & 10.08 & 2.83 & 4.76 & & \\
\hline \multirow{3}{*}{ Differentiated-1 } & $\begin{array}{l}\text { Without } \\
\text { fertilizers }\end{array}$ & 3.24 & 4.46 & 2.81 & 3.03 & \multirow{3}{*}{6.37} & \\
\hline & $\mathrm{N}_{82.5} \mathrm{P}_{60}$ & 6.08 & 11.81 & 3.79 & 7.51 & & \\
\hline & $\mathrm{N}_{120} \mathrm{P}_{60}$ & 6.90 & 14.82 & 4.31 & 7.70 & & \\
\hline \multirow{3}{*}{ Differentiated-2 } & $\begin{array}{l}\text { Without } \\
\text { fertilizers }\end{array}$ & 2.89 & 3.73 & 2.40 & 2.54 & \multirow{3}{*}{5.53} & \\
\hline & $\mathrm{N}_{82.5} \mathrm{P}_{60}$ & 5.34 & 10.28 & 3.37 & 6.28 & & \\
\hline & $\mathrm{N}_{120} \mathrm{P}_{60}$ & 6.13 & 13.01 & 3.94 & 6.43 & & \\
\hline
\end{tabular}


The use of plowless shallow single-depth and differentiated-2 basic soil tillage systems (variant 3,5) resulted in a significant decrease in the yield of all the crops of the crop rotation.

Shallow $(12-14 \mathrm{~cm})$ loosening in the system of prolonged application of a single-depth plowless tillage without application of mineral fertilizers resulted in the formation of the smallest yields in the crop rotation (from $1.77 \mathrm{t} / \mathrm{ha}$ of soybean to $3.05 \mathrm{t} / \mathrm{ha}$ of corn).

\section{Economic and energy efficiency of the crops cultivation in the crop rotation}

Evaluating the efficiency of low-cost - shallow and differentdepth plowless soil tillage systems in the crop rotation, it is necessary to say that providing significant cost savings on their implementation, they had a little influence on the overall expenditures of the crops cultivation technology on the whole (Table 6).

The calculations of the economic efficiency of the fertilizers use at the cultivation of the crops in the crop rotation testify that their application provided the increase of the monetary expenditures per 1 ha of the crop rotation. Thus, on the control variant, the expenditures per 1 ha of the crop rotation averaged to 10,470.7 $\mathrm{UAH}$, with the dose of $\mathrm{N}_{82.5} \mathrm{P}_{60}$ under the same system of basic tillage they increased by $3,356.6 \mathrm{UAH}$ or by $32.1 \%$, at the dose of $\mathrm{N}_{120} \mathrm{P}_{60}-$ by $4,545.6 \mathrm{UAH}$ or by $43.4 \%$.

The highest conditionally pure profit $-27,602.3 \mathrm{UAH}$, on average by the years of the study, was obtained in the variant with the application of mineral fertilizers in the dose of $\mathrm{N}_{120} \mathrm{P}_{60}$ under differentiated-1 system of basic tillage (var. 4). The cost of products in this variant was 42,397.7 $\mathrm{UAH}$, total expenditures - 14,794.0 UAH with the profitability level of $185 \%$.

The increase in the dose of fertilizers increased the conditionally pure profit because the yield increases due to the fertilizers were very considerable.

The highest expenditures for the cultivation of the crops in the crop rotation were in the variant with the system of different-depth plowing basic soil tillage and nitrogen fertilizers application dose of $\mathrm{N}_{120} \mathrm{P}_{60}$, and the lowest ones - 10,155.7 UAH, or by $32.4 \%$ less - at the disk basic tillage system of a single-depth loosening without fertilizers application. 
Table 6

Economic efficiency of the crops cultivation technologies per hectare of the sown area at different basic soil tillage systems in the crop rotation at irrigation (2016-2018)

\begin{tabular}{|c|c|c|c|c|c|c|}
\hline No & 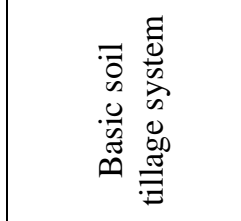 & 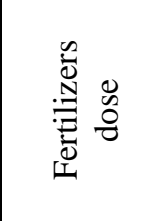 & 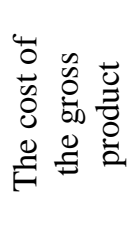 & 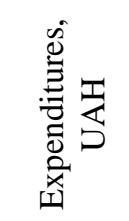 & 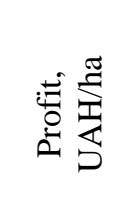 & 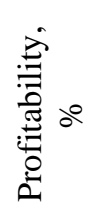 \\
\hline & \multirow{3}{*}{$\begin{array}{l}\text { Plowing } \\
\text { (control) }\end{array}$} & $\begin{array}{l}\text { Without } \\
\text { fertilizer }\end{array}$ & 17743.0 & 10470.7 & 7272.3 & 71.4 \\
\hline 1 & & $\mathrm{~N}_{82.5} \mathrm{P}_{60}$ & 34984.3 & 13827.3 & 21157.0 & 152.7 \\
\hline & & $\mathrm{N}_{120} \mathrm{P}_{60}$ & 40752.7 & 15016.3 & 25736.0 & 170.5 \\
\hline \multirow{3}{*}{2} & \multirow{3}{*}{ Plowless } & $\begin{array}{l}\text { Without } \\
\text { fertilizers }\end{array}$ & 16119.0 & 10312.3 & 5806.7 & 57.9 \\
\hline & & $\mathrm{N}_{82.5} \mathrm{P}_{60}$ & 32757.0 & 13631.7 & 19125.3 & 140.3 \\
\hline & & $\mathrm{N}_{120} \mathrm{P}_{60}$ & 38285.3 & 14832.7 & 23452.7 & 157.5 \\
\hline \multirow{3}{*}{3} & \multirow{3}{*}{ Plowless } & $\begin{array}{l}\text { Without } \\
\text { fertilizers }\end{array}$ & 12654.0 & 10155.7 & 2498.3 & 26.4 \\
\hline & & $\mathrm{N}_{82.5} \mathrm{P}_{60}$ & 25479.3 & 13494.3 & 11985.0 & 89.4 \\
\hline & & $\mathrm{N}_{120} \mathrm{P}_{60}$ & 29008.3 & 14701.3 & 14307.0 & 97.1 \\
\hline \multirow{3}{*}{4} & \multirow{3}{*}{ Differentiated-1 } & $\begin{array}{l}\text { Without } \\
\text { fertilizers }\end{array}$ & 18606.0 & 10248.7 & 8357.3 & 82.9 \\
\hline & & $\mathrm{N}_{82.5} \mathrm{P}_{60}$ & 36860.7 & 13494.3 & 23366.3 & 172.6 \\
\hline & & $\mathrm{N}_{120} \mathrm{P}_{60}$ & 42397.7 & 14794.0 & 27602.3 & 185.0 \\
\hline \multirow{3}{*}{5} & \multirow{3}{*}{ Differentiated-2 } & $\begin{array}{l}\text { Without } \\
\text { fertilizers }\end{array}$ & 15697.3 & 10224.7 & 5472.7 & 55.6 \\
\hline & & $\mathrm{N}_{82.5} \mathrm{P}_{60}$ & 32083.3 & 13537.0 & 18546.3 & 136.2 \\
\hline & & $\mathrm{N}_{120} \mathrm{P}_{60}$ & 37488.3 & 14750.0 & 22738.3 & 152.7 \\
\hline
\end{tabular}

It should be noted that the cultivation of the crops in the crop rotation was profitable in all the studied variants, while the application of the basic disk tillage did not allow obtaining as high profits as on the other variants. The increase of the doses of fertilizers under this system of tillage increased the level of profitabilityonly by $63-70.7 \%$, while the differentiated-1 system provided the increase of $89.7-102.1 \%$. 
Thus, the calculation of the economic efficiency makes possible to claim that cultivation of the crops in the crop rotation at the application of fertilizers in the dose of $\mathrm{N}_{120} \mathrm{P}_{60}$ under the system of differential-1 basic soil tillage is the the most rational and profitable from the economic point of view.

Despite all the advantages of monetary evaluation, the final conviction in the efficiency of production requires the energy assessment.

To establish the energy efficiency of the cultivation technologies of the crops in the crop rotation we used such indexes: yield, energy expenditures for the crop cultivation, energy income with the product, energy increase, energy coefficient.

Our calculations proved that technological expenditures for the application of mineral fertilizers contributed to the increase of the energy consumption

The highest technological expenditures were determined in the variant of the system of plowing basic tillage with plowing under the crops of the crop rotation on the depth of 14-16 - 25-27 cm and application of mineral fertilizers in the dose of $\mathrm{N}_{120} \mathrm{P}_{60}-39.7 \mathrm{GJ} / \mathrm{ha}$, while the least energy expenditures $(35.2 \mathrm{GJ} / \mathrm{ha})$ were in the variant with disk loosening on $12-14 \mathrm{~cm}$ in the system of plowless shallow singledepth tillage without application of nitrogen fertilizers (Table 7).

Table 7

Energy efficiency of the crop cultivation technology at different soil tillage and fertilization systems

\begin{tabular}{|c|l|c|c|c|}
\hline \multirow{2}{*}{ No. } & \multicolumn{2}{|c|}{ Soil tillage system } & \multicolumn{3}{|c|}{\begin{tabular}{c} 
Indexes of the efficiency \\
\cline { 3 - 5 }
\end{tabular}} & $\begin{array}{c}\text { Energy } \\
\text { expenditur } \\
\text { es, GJ }\end{array}$ & $\begin{array}{c}\text { Output of the } \\
\text { gross energy, } \\
\text { GJ }\end{array}$ & EC \\
\hline 1 & 2 & 3 & 4 & 5 \\
\hline \multicolumn{4}{|c|}{ System of Fertilizing No. 1 (without fertilizera) } \\
\hline 1 & Different-depth plowing & 37.8 & 62.9 & 1.7 \\
\hline 2 & Different-depth plowless & 36.4 & 57.0 & 1.6 \\
\hline 3 & $\begin{array}{l}\text { Single-depth shallow } \\
\text { plowless }\end{array}$ & 35.2 & 46.2 & 1.3 \\
\hline 4 & Differentiated-1 & 36.1 & 66.0 & 1.8 \\
\hline 5 & Differentiated-2 & 35.9 & 55.3 & 1.5 \\
\hline
\end{tabular}


End of Table 7

\begin{tabular}{|c|l|c|c|c|}
\hline 1 & \multicolumn{1}{|c|}{2} & 3 & 4 & 5 \\
\hline \multicolumn{4}{|c|}{ System of Fertilizing No. 2 with the application of $\mathrm{N}_{82.5} \mathrm{P}_{60} \mathrm{~kg} / \mathrm{ha}$} \\
\hline 1 & Different-depth plowing & 38.7 & 134.4 & 3.5 \\
\hline 2 & Different-depth plowless & 37.9 & 126.1 & 3.3 \\
\hline 3 & $\begin{array}{l}\text { Single-depth shallow } \\
\text { plowless }\end{array}$ & 36.1 & 98.2 & 2.7 \\
\hline 4 & Differentiated-1 & 37.0 & 141.6 & 3.8 \\
\hline 5 & Differentiated-2 & 36.8 & 121.3 & 3.3 \\
\hline \multicolumn{4}{|c|}{ System of Fertilizing No. 3 with the application of $\mathrm{N}_{120} \mathrm{P}_{60} \mathrm{~kg} / \mathrm{ha}$} \\
\hline 1 & Different-depth plowing & 39.7 & 156.8 & 4.0 \\
\hline 2 & Different-depth plowless & 38.2 & 147.6 & 3.9 \\
\hline 3 & $\begin{array}{l}\text { Single-depth shallow } \\
\text { plowless }\end{array}$ & 37.0 & 113.4 & 3.1 \\
\hline 4 & Differentiated-1 & 37.9 & 159.5 & 4.2 \\
\hline 5 & Differentiated-2 & 37.7 & 141.7 & 3.7 \\
\hline
\end{tabular}

Evaluating the energy efficiency of the crop cultivation technologies in the crop rotation at irrigation, it is possible to conclude that they are all sufficiently effective, at the same time, the maximal energy coefficient of 4.0-4.2 was obtained at the cultivation of the crops in the crop rotation at differentiated-1 basic tillage and application of mineral fertilizers in the dose of $\mathrm{N}_{120} \mathrm{P}_{60}$. The minimal index (1.3) was on the non-fertilized plots and disk tillage on the depth of $12-14 \mathrm{~cm}$.

\section{CONCLUSIONS}

Therefore, to obtain the profitability level of production of $185 \%$, energy coefficient of 4.2 conventional units and the optimum agrophysical properties of the soil on the irrigated lands, it is necessary to use differentiated-1 system of basic soil tillage, in which during the crop rotation all the crops receive disk tillage, and sorghum receives chisel loosening followed by slotting to the depth of $38-40 \mathrm{~cm}$ and fertilization with the dose of $\mathrm{N}_{120} \mathrm{P}_{60} \mathrm{~kg}$ per 1 hectare of the sown area.

\section{SUMMARY}

Goal: To substantiate scientifically the optimum parameters of the ratio of the competitive crops, minimized soil tillage and doses of nitrogen fertilizers, which will ensure the preservation of soil fertility, 
resources saving and the increase of the productivity in the conditions of Southern Steppe. Methods: field, quantitatively-weight, visual, laboratory, calculation-comparative and mathematical-statistical methods with the use of generally accepted in Ukraine methods and methodological recommendations. Results. On average for 3 years of the study, the use in the study of a different-depth plowing and differential-1 systems of basic tillage system ensured the formation of the optimum agrophysical indexes for the plants in the crop rotation at the stage of sprouts and the initial stages of organogenesis. By the time of harvesting, the indexes increased, while the regularity, found out at the beginning of spring vegetation, remained. On average for three years of the study, it was found that the highest yield of the crops in the crop rotation were provided by the fertilizers dose of $\mathrm{N}_{120} \mathrm{P}_{60}$ on the background of different-depth and differentiated-1 systems of tillage. Thus, the yield of grain corn was 14.44 and $14.82 \mathrm{t} /$ ha, respectively, soybean -4.31 and $4.34 \mathrm{t} / \mathrm{ha}$, winter wheat 6.81 and $6.90 \mathrm{t} / \mathrm{ha}$ and grain sorghum -7.09 and $7.70 \mathrm{t} / \mathrm{ha}$. The highest conditional pure profit $27,602.3$, on average by the years of the study, was received in the variant with the application of mineral fertilizers in the dose of $\mathrm{N}_{120} \mathrm{P}_{60}$ in the system of differentiated-1 basic tillage. Conclusions: Therefore, to obtain the profitability level of production of $185 \%$, energy coefficient of 4.2 conventional units and the optimum agrophysical properties of the soil on the irrigated lands, it is necessary to use differentiated-1 system of basic soil tillage, in which during the crop rotation all the crops receive disk tillage, and sorghum receives chisel loosening followed by slotting to the depth of $38-40 \mathrm{~cm}$ and fertilization with the dose of $\mathrm{N}_{120} \mathrm{P}_{60} \mathrm{~kg}$ per 1 hectare of the sown area.

\section{REFERENCES}

1. Філіп'єв I. Д., Гамаюнова В. В., Димов О. М. Поживний режим грунту при полицевому i безполицевому обробітку. Зрошуване землеробство: 3б. наук. пращь. Київ: Аграрна наука, 1997. Вип. 41. С. 31-34.

2. Нетіс I. Т. Посухи та їх вплив на посіви озимої пшениці. Херсон: Айлант, 2012. 250 с.

3. Системи землеробства на зрошуваних землях / за науковою редакцією Р.А. Вожегової. Київ: Аграрна наука, 2014. 264 с. 
4. Наукові основи виробництва органічної продукції в Україні / за науковою редакцією Я.М. Гадзала, В.Ф. Камінського. Київ: Аграрна наука, 2016. 588 с.

5. Коваленко А. М. Екологічні аспекти побудови сівозмін короткої ротації на зрошуваних і неполивних землях. Зрошуване землеробство. Херсон: Айлант, 2006. Вип. 45. С. 52-55.

6. Методика польових i лабораторних досліджень на зрошуваних землях: монографія / Р.А. Вожегова та ін. Херсон: Грінь Д.С., 2014. 286 с.

7. Статистичний аналіз результатів польових дослідів у землеробстві: монографія / Ушкаренко В.О. та ін. Херсон: Айлант, 2013. $410 \mathrm{c}$.

\section{Information about the author: \\ Maliarchuk A. S.,}

Candidate (Ph.D.) of Agricultural Sciences, Senior Researcher of Department of Irrigated Agricultural, Institute of Irrigated Agriculture of the National Academy of Agrarian Sciences of Ukraine Kherson, Naddniprianske, 73483, Ukraine 